\title{
LEADING PEDAGOGICAL APPROACHES TO SCIENTIFIC AND METHODOLOGICAL SUPPORT IN PREPARATION FOR SUBJECT OLYMPIADS AT THE UNIVERSITY
}

\author{
Tatiana Larina ${ }^{1}$, Veronika Romanchuk2, Ekaterina Volkova ${ }^{3}$, Evgeny Litvinov ${ }^{4}$, \\ ${ }^{1}$ Doctor of Sciences (Pedagogy), Professor, Military Educational Scientific Center of the Air Force \\ "N.E. Zhukovsky and Y.A. Gagarin Air Force Academy, St. Bolshevikov street, 54A Voronezh, \\ Russia, e-mail: tanialar2008@yandex.ru \\ ${ }^{2}$ Candidate of Sciences (Pedagogy) Associate Professor, \\ Military Educational Scientific Center of the Air Force "N.E. Zhukovsky and Y.A. Gagarin Air Force \\ Academy, St. Bolshevikov Street, 54A Voronezh, Russia, \\ e-mail: veronika.romanchuk@gmail.com \\ ${ }^{3}$ Doctor of Historical Sciences, Associate Professor, Voronezh State Technical University, 20 years \\ of October Street, 84, Voronezh, Russia, e-mail: volkne@bk.ru \\ ${ }^{4}$ Doctor of Medical Sciences, Voronezh State Technical University, 20 years of October street, 84, \\ Voronezh, Russia, e-mail: litvinova-76@inbox.ru
}

\begin{abstract}
The article examines the theoretical and practically significant components of high-quality and competent scientific and methodological support in preparation for subject Olympiads in higher education. The authors update and present the theoretical and practical substantiations of the verified scientific and methodological regulation designed to improve the training of participants in the Olympiads. The main pedagogical approaches that contribute to improving the quality of preparation of participants for subject Olympiads in universities are highlighted.
\end{abstract}

Keywords: educational process, Olympiad movement, methods of education, scientific and methodological support

\section{INTRODUCTION}

Modernization and qualitative reform of the higher education system with the aim of a qualitatively new, effective, promising development of Russian society and the country provide for an appeal to innovative approaches to educational activities of students, require constant updating of scientific and methodological support of the educational process and the continuous progress of educational technologies. The current situation in the system of modern education is determined by the characteristic prerequisites for a fundamental increase in the level of education in higher education. Such prerequisites are directly interconnected with the determination of the needs for special training in higher education, the improvement and complication of requirements for the quality of training of specialists, with the formation of favorable conditions for the development of their internal culture.

A significant stimulating factor in improving the quality of the educational process in higher education is increasing the scale of fundamental training, the priority component of which is the cognitive process, which invariably stimulates the adaptation of future specialists in various circumstances of professional activity.

The process of modernization of higher education is aimed at innovative educational activities in the field of organizing the pedagogical process, realizing the task of continuity and versatility, which invariably sets the search vector for the intensity of systematization of the content of education in various aspects of its scientific and methodological support. The analysis of scientific literature allows us to conclude that the 
scientific and methodological support at the university is a dynamic methodological complex, consisting of fundamental scientific achievements and fundamental practical experience, which aim to timely develop scientifically-based, normative-methodological, educational program documents and extensive information resources for training future specialists.

Based on a solid foundation of extensive pedagogical practice, the creation of optimal scientific and methodological support for participants in the educational process of higher education is a complex and laborious process, a complex and multifaceted task. For its successful and effective solution for teachers of higher education, it is not enough just competence in the field of the taught discipline and pedagogical skill in the issue of technology for revealing the inner potential of the student's personality, the formation of his knowledge and competencies. An accurate understanding of the system of the educational and methodological complex of the discipline, its composition, verified structure and content, various requirements for its development, technologies and methods for creating such a complex is also necessary.

Participation in subject Olympiads and competitions in academic disciplines of the university is fertile ground for deep, systematic and comprehensive assimilation of subject knowledge, awareness of the integral nature of personality cognition, the ability to develop non-standard creative thinking of the inventor, nourish and nurture the willingness of future specialists to innovative activities in the professional sphere.

\section{METHODOLOGY}

The contextual approach, as one of the fundamental pillars of the formation and development of the educational Olympiad environment, poses a variety of tasks for the teacher, overcoming which means honing pedagogical skills and accumulating valuable pedagogical experience.

Based on an integrated approach, we talked about designing an effective scientific and methodological content of the educational process, and having considered the contextual pedagogical approach, we cannot but focus on the dominance of active teaching methods, which are so beneficially used in the wellcoordinated work of the Olympiad team. It is important to define here that by active methods we mean such teaching methods, when implemented, the educational, scientific and cognitive activity of the student is productive, search-creative and constructive.

The third leading pedagogical approach in the process of organizing scientific and methodological support in preparation for subject Olympiads is the activity approach (L.S.Vygotsky, A.N. Leontyev, D.B. Elkonin, P.Ya. Galperin, V.V.Davydova and etc.). Making a conclusion about the importance of the activity approach in the development of high-quality scientific and methodological support in preparation for various competitive competitions, it is necessary to conclude that educational activity in this case should be a process of personal transformation, and transformation in any of its form entails a natural breakdown of the old thinking and the transition to quality new level.

\section{DISCUSSION}

Theoretical analysis and experience of the existing work in the preparation and conduct of competitive competitions (olympiads) showed that the following pedagogical approaches are most effective for highquality scientific and methodological support: an integrated, contextual and activity-based approach.

In modern pedagogical research, the concept of an integrated approach appears quite often (Yu.K. Babansky, M.M. Potashnik, M.V. Kabatchenko, G.L.Smirnov, etc.), since its key idea of use involves the need to solve multilevel problems comprehensively and efficiently. Here, under the complex it is customary to understand the totality of phenomena and objects as an integral whole.

In contrast to the systemic approach, where there is an emphasis on one's own vision of the situation, in an integrated approach the emphasis is placed precisely on a variety of activities that presuppose its deep knowledge and awareness. In an integrated pedagogical approach, an interdisciplinary vision of the educational process is purposefully built and strengthened.

An integrated pedagogical approach aims at the ability of a higher school teacher to direct the student towards the development of skills to go beyond the limits of everyday learning and to consider any difficulty as an incentive for further personal progress. It follows that this step in our strategy for designing competent scientific and methodological support in preparation for the Olympiad is aimed at the value-target orientation of vocational training, in promoting the formation and development of personal characteristics of students, which are indicators of a person's professional development. The task of high-quality scientific and methodological support, stimulated and guided by an integrated approach, is additionally simplified and competently guided by the contextual pedagogical approach (AA Verbitsky, NB Lavrentieva, etc.) 
The contextual approach, as one of the fundamental pillars of the formation and development of the educational Olympiad environment, poses a variety of tasks for the teacher, overcoming which means honing pedagogical skills and accumulating valuable pedagogical experience.

Based on an integrated approach, we talked about designing an effective scientific and methodological content of the educational process, and having considered the contextual pedagogical approach, we cannot but focus on the dominance of active teaching methods, which are so beneficially used in the wellcoordinated work of the Olympiad team. It is important to define here that by active methods we mean such teaching methods, when implemented, the educational, scientific and cognitive activity of the student is productive, search-creative and constructive.

The third leading pedagogical approach in the process of organizing scientific and methodological support in preparation for subject Olympiads is the activity approach (L.S.Vygotsky, A.N. Leontyev, D.B. Elkonin, P.Ya. Galperin, V.V.Davydova and etc.). [7]. Making a conclusion about the importance of the activity approach in the development of high-quality scientific and methodological support in preparation for various competitive competitions, it is necessary to conclude that educational activity in this case should be a process of personal transformation, and transformation in any of its form entails a natural breakdown of the old thinking and the transition to quality new level.

\section{RESULTS}

Thus, having carefully studied and analyzed the complex, contextual and activity-based pedagogical approaches, substantiating their fundamental significance and relevance specifically for preparing for subject Olympiads, we consider it legitimate to conclude that high-quality scientific and methodological support of this process will allow:

- To increase the effectiveness of the personal value and professional competence of future specialists as subjects of the process of education in the field of science and practice, conditioned by the goals, motives and characteristics of professional activity, which provides for the willingness to solve the assigned tasks in various non-standard situations on the basis of professional competencies and self-actualization of the individual;

- To correctly select the most valuable information resources available;

- To form the readiness of students for continuous self-education and self-development for the entire period of study at the university;

- To stimulate motivation for continuous creative creation and self-improvement of future specialists in future professional activities.

\section{CONCLUSION}

Summing up the theoretical substantiation of the scientific and methodological support and regulation of key pedagogical approaches, it should be noted that any pedagogical activity is characterized by the presence of a clearly defined goal that is personally significant for the teacher carrying out this activity and is motivated by the motives arising from it. Competent educational activity in the process of preparing for the Olympiad in any subject can be successfully carried out only when the scientific and methodological base clearly defines and solves specific educational Olympiad problems.

\section{REFERENCE LIST}

Ashmarov I.A., Bobrovnikova M.A., Volkova E.A. (2016). On state policy in the sphere of regional education. Region: systems, economics, management. Pp.90-97. (in Russ).

Ashmarov I.A., Volkova E.A., Frolova E.V (2015) To the question of formation of trends in the higher education system in the framework of modern globalization processes. Modern problems of science and education.. No. 1-1. Pp 975 - 977.

Chekmeneva T.G., Ershov B.A., Trubitsyn S.D., Ostapenko A.A. (2020) Chinas Information Security Strategy: Political and Technical Aspects. Bulletin Social-Economic and Humanitarian Research. Volume 7. Number 9. Pp. 78 - 97. doi: 10.5281/zenodo.3911320 (in Russ). 
Ershov B.A. (2010) The Russian Orthodox Church and secular power in the Voronezh province in the XIX early XX centuries. GOU VPO "Voronezh State Technical University". Voronezh. 167 p. (in Russ).

Ershov B.A. (2010) The system of spiritual education in Voronezh province in the 19th century. Education and Society. №. 5 (64). Pp. 105-108. (in Russ).

Ershov B.A., Fursov V.N. (2018) The Russian Church in the State Mechanism of Russia. Bulletin SocialEconomic and Humanitarian Research. № 1. Pp. 32-37. (in Engl).

Ershov B.A., Perevozchikova L.S., Romanova E.V. (2019) Globalization and Intensification of Spiritual Values in Russia in the Philosophical Aspect. 6th International Conference on Education and Social Sciences Abstracts \& Proceedings. Pp. 208-212. (in Engl).

Ershov B.A., Perevozchikova L.S., Romanova E.V., Ashmarov I.A. (2019) The Concept of Spirituality in Social Philosophy. Smart Innovation, Systems and Technologies. T. 139. Pp. 688-694. (in Engl).

Glyavin Yu. V. (2002) How to deal with talented youth? // Integration of humanitarian, fundamental and professional knowledge in education of the XXI century: materials scientific method. conf. Part 2. Novocherkassk: YURSTU, Pp.7-14. (in Russ).

Larina T.V. (2020) Modern approaches to managing the quality of the educational process. Methodology. Aerospace forces. Theory and practice. No. 16. Pp.307-314. (in Russ).

Rodionova V.D.(2005) Scientific and methodological support of teachers' activities in the system of secondary vocational education: on the example of educational institutions of light industry: dissertation ... candidate of pedagogical sciences: 13.00.01. Kazan. state un-t. - Kazan, 180 p. (in Russ).

Sidelnikova T.T. (2006) The system of innovative scientific and methodological support for professional training of political science students: abstract of thesis. ... doctors of pedagogical sciences: 13.00 .08 / Kazan. state un-t. - Kazan,.- 44 p. (in Russ).

Starodubets E.E., Petrova T.P., Borisevich S.V. (2014) The role of student Olympiads in the development of higher professional education // Bulletin of Kazan Technological University. No. 16. Pp.37-39 URL: https://cyberleninka.ru/article/n/rol-studencheskih-olimpiad-v-razvitii-vysshego-professionalnogoobrazovaniya . (in Russ).

Volkova E.A., Frolova E.V. (2016). Conditions for increasing the quality of the system of Russian higher education at the modern stage. // Actual problems of professional education: goals, objectives and prospects for development. collection of scientific articles based on the materials of the 14th allRussian correspondence scientific and practical conference. Pp.186-192. (in Russ).

Volkova E.A., Frolova E.V. (2017) Features of teaching humanities disciplines in technical universities (on the example of vstu) // Actual problems of vocational education: goals, objectives and development prospects. Collection of scientific articles based on the materials of the 15th all-Russian correspondence scientific-practical conference. Voronezh branch of the Russian Academy of National Economy and Public Administration under the President of the Russian Federation. Pp. 72-76. (in Russ). 